Шабаль К. С.

здобувач кафедри української літератури Запорізький національний університет

\title{
ПРОБЛЕМА «ЛЮДИНА І ВЛАДА» В СУЧАСНОМУ ПОЛІТИЧНОМУ РОМАНІ
}

У статті проаналізовано проблему зіткнення особистості та влади в політичному романі. Зроблено спробу дослідити особливості жанрового різновиду. Зосереджено увагу на авторському баченні політичного конфлікту в романах «Заплава» В. Баранова та «Записки украӥнського самамедшого» Л. Костенко. Осмислено тендениї й перспективи розвитку жанрового різновиду за сучасної літературної динаміки.

Ключові слова: алюзія, влада, людина, політичний дискурс, політичний роман.

В статье проанализировано проблему столкновения личности и власти в политическом романе. Сделана попытка исследовать особенности жанровой разновидности. Внимание сосредоточено на авторском видении политического конфликта в романах «Заплава» В. Баранова и «Записки украинского сумастедшего» Л. Костенко. Осмысленно тенденщии и перспективы развития жанровой разновидности в современной литературной динамике.

Ключевые слова: аллюзия, власть, человек, политический дискурс, политический роман.

The article analyzes the problem of personality clashes and political power in the novel. An attempt was made to study the peculiarities of the genre variety. Focuses on the author's vision of the political conflict in the novels «Floodplain» by V. Baranov and "Notes of a Ukrainian Madman» by L. Kostenko. Meaningful trends and prospects of development of genre variety in modern literary dynamics.

Key words: allusion, authority, people, political discourse, political novel.

Ставлення людини до політичного життя і влади було та $є$ предметом тривалих суперечок. Чому ж окремі люди цікавляться політикою і прагнуть влади, а інші - ні? Великий вплив на розвиток вчення про владу і людину мали погляди Конфуція, Платона, Аристотеля. Так, Платон уважав, що вчення про владу і людину має грунтуватись передусім на вивченні людини, але визнавав безумовне верховенство держави над індивідом. Державою повинні керувати 
найбільш розумні та благородні люди, а від небажаних осіб необхідно «звільнятись» за допомогою смертної кари та вигнання. Аристотель, вважав, що людина мусить бути політичною i колективістською істотою. Держава, за Аристотелем, - засіб вираження та узгодження інтересів усіх груп суспільства, засіб підтримки соціального миру й справедливості, засіб забезпечення гідності й соціального захисту всіх громадян [6]. Світ влади нескінченно різноманітний, але він відбиває індивідуальність володарів, умов існування і буття. Тобто, у самій владі, як феномені, породженому функціонуванням живих, мислячих істот, мимоволі виявляються риси, які відтворюють аналоги якостей людини у всьому їхньому спектрі - від найцінніших до найогидніших рис та виявів.

Проблема влади існувала завжди. Силою влади, iii авторитетом здійснюються політичні акції, загострюється чи послаблюється соціальна напруженість та конфронтація. Зі станом влади, рівнем іiі організації, люди сподіваються розв’язання економічних і соціальних проблем. Наділяючи носіїв влади пільгами, які матеріально та юридично надають їм привілеїв, людина перетворює владу на предмет потаємних бажань і боротьби за неї. Тож влада суспільне явище, з яким пов’язані зло і розбрат, трагедії і потрясіння. Ніщо не вимагало стільки жертв, скільки боротьба за владу - за політичне, економічне й духовне панування.

Проблема «людина та влади» - наскрізна у світовій літературі, зокрема в художній дійсності політичного роману. Отже, мета статті - аналіз проблеми зіткнення особистості та влади в політичному романі - передбачає вирішення таких завдань: виокремити цю проблему як домінантну в ідейному спрямуванні політичного роману; довести, що в політичному романі конфлікт висувається на перший план, а долі героїв розглядаються крізь його призму; виділити проблемно-тематичний комплекс творів «Заплава» В. Баранова та «Записки українського самашедшого» Л. Костенко.

Визначення статусу політичного роману як жанрового різновиду суперечливе. За Б. Проскуріним, питання про його ідентифікацію є складним у сучасних умовах, коли широко постулюється теза про ворожість політики будь- 
якій творчості. Під політичним романом розуміємо твір, у якому політичні ідеї $\epsilon$ домінуючими, або в якому політична ситуація $є$ головним об'єктом художнього зображення. Однак західні літературознавці визнають соціальноідеологічну основу політичного роману закономірною, але при цьому ставлять знак рівності між поняттями «політичний роман» і «роман ідей». Наприклад, професор Дж. Девідсон у визначенні політичного роману керується таким: сюжет роману - політика, мета - переконання, літературні засоби - будь-які, залежно від необхідності [Davidson 1961:851]. Він вважає, що роман може бути політичним, якщо автор має намір переконати читача в правоті певних політичних ідей і поглядів.

Політичний роман містить, 3 одного боку, найбільш суттєві складові політичної свідомості, включаючи концепти, стереотипи, цінності, мотиви, ідеології, політичні погляди, тактики і стратегії, характерні для соціуму в певний історичний період і відображені в політичному дискурсі цього соціуму. Політичний роман - жанровий різновид художнього i політичного видів дискурсу, на відміну від інших жанрових утворень політичного дискурсу (політичні дебати, публічна промова, урядові постанови, інавгураційне звернення), що безпосередньо впливає на політичні погляди, цінності та дії. Він сприяє формуванню політичної свідомості через естетичний вплив, тобто непрямим чином. Водночас, включає індивідуальні погляди, установки, інтенції, переконання, які в сукупності відображають авторське сприймання та оцінку політичної дійсності, представлені крізь призму художньої свідомості. Тобто, політичний роман - особистісна, художньо обумовлена експлікація інформації про політичну дійсність.

В українській літературі політичний роман малодосліджений, а поняття «політичний роман» відсутне в українських літературознавчих енциклопедіях i довідниках. Про жанрово-стильові особливості сучасного політичного роману писали $\quad$ В. Климчук, $\quad$ I. Моторнюк, М. Слабошпицький. Грунтовніші дослідження цього жанрового різновиду у зарубіжній літературі. Д. Затонський у праці «Художні орієнтири $\mathrm{XX}$ століття», присвяченій дослідженню 
британського політичного роману, зауважував: «Політичний роман» - изе поняття жанрове. I в такій уже формі, яка склалася $і$ володіє специфічними рисами, він - породження XX cm.» (переклад - Ш. К.) [Затонский 1988:373]. Науковець стверджував, що сучасний політичний роман не виник на пустому місці, звичайно ж, у нього були «твори-попередники». Історія англійської літератури і до XIX ст. дає приклади художньої «роботи» 3 політикою, але здебільшого в «малих» формах - історичних хроніках і трагедіях К. Марло, В. Шекспіра, політичних одах, сатирично-політичних поемах, памфлетах, сатиричних новелах і нарисах, політичних комедіях Д. Мільтона, Д. Свіфта, Д. Дефо, Д. Аддісона, О. Поупа, Г. Філдінга та інших. У романах політичні епізоди довгий час існували в якості «вкраплень» i не домінували навіть у проблемно-тематичній структурі, здебільшого залишаючись частиною загальної лінії відтвореного життєвого шляху героя або громадської панорами. Або автор, уникаючи прямого зображення політики, використовував іносказання, найчастіше іронічне або сатиричне (згадаймо політичні іносказання Д. Свіфта у романі «Мандри Лемюеля Гуллівера»). Однією 3 перших «моделей» політичного роману Д. Затонський назвав книгу А. Мальро «Умови людського існування» (1933р.), мотивуючи тим, що вона містить гострий сюжет, змальовує повсякденність буття в напівколоніальному Китаї, i має, якщо не документальну, то в усякому разі журналістську манеру письма.

У сюжетно-фабульній основі політичного роману лежить політичний конфлікт, єдиноборство у сфері владних відносин, народжене зіткненням різних політик (різного рівня і масштабів). Реалізується цей тип конфлікту в детермінованих йому характерах законодавців, державних діячів, партійних функціонерів, а також простих людей, які все більше втягуються в політику самою дійсністю, тобто характерах, які мають безпосереднє, постійне або тимчасове, нехай тільки в рамках відтворених у романі обставин, ставлення до політики. Політичний роман - це твір про взаємодію людської особистості та політики, i тому він перебуває на стику «людинознавства» i політики. Як правило, в романі втілюється серйозна політична (політологічна) ідея, яка 
реалізується в діях персонажів. У змістовому i сюжетному просторі твору політика завжди впливає на людину комплексно й різноспрямовано, грає структуроутворюючу роль, але не витісняє інших аспектів людської поведінки, a $\epsilon$ своєрідним його драматизуючим каталізатором. Письменник, зосереджуючись на долі окремої людини i нарочито цю окремішність підкреслюючи, концентрує увагу на перетині життя пересічної особистості та загальних закономірностях, загострених політикою. Ця ознака жанрового різновиду чітко прослідковується в таких творах, як «Чорний Ворон» В. Шкляра, «Музей покинутих секретів» О. Забужко, «Заплава» В. Баранова, «Країна ірредента» Р. Іваничука, «Записки українського самашедшого» Л. Костенко.

У час становлення української держави посилюється увага до перебігу політичних подій, тому виникає потреба задовольняти читацький інтерес у літературі відповідної тематики. У політиці сьогодення досить часто ті чи інші рішення визначаються не рівнем професійної підготовки чи духовності людини, а жадобою до влади й багатства. Ця проблема гостро постає i в реальному житті, і в художній дійсності політичного роману.

Роман «Заплава» В. Баранова - контроверсійний. В образі головного героя - журналіста Артема - письменник втілив потребу ненависті до несправедливості та беззаконня, ненависті - катарсисної, яка має вибухнути задля оговтання зомбованого суспільства, реальної протидії представникам продажницької влади. Доля персонажів вивершується в час Помаранчевої революції. Оповідь ведеться від першої особи, що забезпечило ефект незримої присутності реципієнта поруч з героями твору. Сюжетні колізії постають у формі строкатих, але дотичних між собою картин, спогадів.

Сфера зацікавлень В. Баранова в «Заплаві» - це актуальні проблеми суспільно-політичного характеру, які грунтуються на загальнонаціональних інтересах народу. Роздуми над долею героя (його проблемами, загрозою його фізичного знищення) письменник протиставляє всьому тому, що заважає Україні бути насправді вільною та незалежною. На наш погляд, в ідейному 
спрямуванні роману проблема «людина i влада» $\epsilon$ провідною. Вона ж завуальовано криється, власне, і в назві твору. У прикінцевому розділі «Замість епілогу» автор дає тлумачення слова «заплава», посилаючись на одинадцятитомне видання словника української мови: «заплава - частина річкової долини, щзо затоплюється під час весняної повені» [Баранов 2013:339]. Це алегорія Майдану: як ріка, що виходить зі своїх берегів, розливається й очищує все навкруги. Так і українці вийшли на Майдан, щоб повстати проти невитруйної корупції та ошуканства. Друге значення взято зі словника Б. Грінченка: «плавающіе на реке въ половодье дрова, камыщъ, щуепки и пр.» [Баранов 2013:339], тобто це весь непотріб, що несе вода, під час повені. Це друга алегорія. Адже Майдан не виправдав сподівань народу, зневіру й розчарування принесли новообрані лідери українцям, бо невдовзі після Помаранчевої революції вони віддали владу «Слонам»: «Україна батьківщина Слонів» [Баранов 2013:323].

Бачимо в романі елементи політичної алюзії. Алюзія - художньостилістичний прийом, натяк, відсилання до певного літературного твору, сюжету чи образу, а також історичної події з розрахунку на ерудицію читача, покликаного розгадати закодований зміст [ЛСД 2007:29-30]. У творі замасковано прізвища претендентів на посаду президента i деяких відомих політичних діячів: Гощенко, Новаковський, Шутін, Гоча Хундадзе, але в контексті зрозуміло, про кого йдеться насправді. У роман введено образ-символ «Слона», під яким вбачаємо людей, які не мають власних ідейних переконань, почуття патріотизму, честі та порядності. Засліплені прагненням до наживи, вони займаються політичним прислужництвом задля власної кар’єри: «Якщо політик не продається за гроші, то він продається за великі гроші» [Баранов 2013:203]. Головний герой змушений рятуватися втечею до Москви за свої розслідування, бо, як журналіст, він не може пройти повз гарячі теми скажімо, рейдерського захоплення київських автостоянок для побудови прибуткових «висоток» або силового схиляння медичних працівників до встановлення «потрібних» владі діагнозів. Із вибухом Майдану Артем 
повертається до Києва з надією моральної сатисфакції, зі впевненістю, що його переслідувачів-«слонів» буде покарано: «Думалося: опоненти системи, яких несподівано для влади дружно підтримав народ, щуо його вже й за народ ніхто не вважав, скрутить їй роги і в моїи рідній краӥні більще не правитимуть балу новоявлені демони» [Баранов 2013:231], що нова влада не допустить розгулу злочинності, яка фінансувалася людьми, які займали керівні посади, або ж кримінальними авторитетами. Але, потрапивши на Майдан, герой бачить, що одним із оплічників нового президента $є$ Слон. Зло залишилося не тільки не покараним, а ще й отримало доступ до влади. Це бачить журналіст, а згодом і зрозуміє зраджений народ. Обираючи героєм твору людину такої професії, письменник показав, що справжня вільна й непідкупна журналістика ще існує в Україні, а це значить, що є люди, моральними орієнтирами яких $є$ добро, правда, справедливість. Згадує романіст гучну справу з вбивством Георгія Гонгадзе, чим підкреслює значення свого головного персонажа.

Щоб передати суперечності складної політичної ситуації в країні та ставлення чиновників до свободи слова Л. Костенко у «Записках українського самашедшого» теж пильно вдивляється в особу вбитого журналіста: «Справа Гонтадзе - остання крапля, щзо переповнила чашу терпіння» [Костенко 2012:39]. У романі письменниця зачіпає всі актуальні проблеми українського суспільства, торкається й теми конфліктності між пересічною особистістю та владою. Висловлюється недовіра до влади та механізму управління державою: авторка акцентує на фальсифікації виборів в Україні, неспроможності уряду приймати зважені рішення. Змальовується морально-етична ницість керівників держави; класова нерівність людей у суспільстві; непоборна корупція, що дає право купувати депутатам місця в парламенті; зомбування українців потрібною інформацією; безкарність криміналу та злочинності. Л. Костенко говорить про формування влади людьми, яким небайдужа подальша доля їхніх батьків, дітей та онуків, головне, щоб «вони, ставщи владою, не зрадили цчей Майдан» [Костенко 2012:414]. Виразник ідей письменниці - головний герой засуджує людей, які прагнуть завоювання, використання та утримання політичної влади. 
Не приховує обурення щодо тіньових елементів політичної системи України, якими $є$ політичні клани, парламентське лобі, оточення перших осіб держави. Якщо ж порівняти фінали творів В. Баранова та Л. Костенко, то вони не схожі між собою. У «Заплаві» герой терпить повне фіаско. Артем опиняється у святошинському кафе-барі «Paradise», слухаючи російську попсу, замовляючи собі випити, розуміє провал усіх сподівань на краще майбутнє: «A перед очима - голуб, який не дався до рук помаранчевому переможиеві» [Баранов 2013:338]. У Л. Костенко - навпаки, у фіналі роману відчувається оптимізм, 3'являється розуміння того, що Майдан був таки недаремно, що революція дала поштовх для пробудження нації: «Все одно за владу буде соромно, за будь-яку владу час від часу буває соромно. А от за Украйну соромно вже не буде» [Костенко 2012:403].

Політроманісти акумулюють думку, що для успіху влади, іiі стабільності необхідно, щоб вона не була налаштована проти людини, проти народу, а слугувала i захищала їх. Дуже важливо, щоб цьому сприяв надзвичайно складний комплекс, який стосується усіх і кожного, - комплекс розумних владних інтересів, владних відносин, владної свідомості.

Політика все глибше й сміливіше входить в усі сфери соціального життя людини, тому, очевидно, що політичний вибір є важливим, і впливає, а то й визначає іiі життя. Українська політична проза має стати однією 3 впливових сил в осягненні багатогранної історичної спадщини українського народу, важливим пізнавальним методом у розкритті психології нації, влади i можновладців, що призведе до духовного перевороту в свідомості мільйонів людей, які по-новому почнуть поціновувати історію й сучасність. У цьому вбачаємо значимість політичного роману як жанрового різновиду. Можливість дослідження проблеми «людина і влада» не обмежується текстами політичних романів і потребує окремих літературознавчих студій.

\section{БІБЛІОГРАФІЯ}

Баранов 2013 - Баранов В. Смерть по-білому. Заплава : романи / В. Баранов. - К. : Ярославів Вал, 2013. - 360 с. 
Davidson 1961 - Davidson J. Political Science and Political Fiction// American Political Science Review. - Vol. 55. - No. 4. - 1961. - pp. 851-860.

Затонский 1988 - Затонский Д. Художественные ориентиры XX века [Электронный ресурс] / Д. Затонский. - Москва, 1988. - 416 с. - Режим доступа: http://www.gumer.info/bibliotek_Buks/Literat/zaton/11.php.

Костенко 2012 - Костенко Л. Записки українського самашедшого / Л. Костенко. - К. : А-БА-БА-ГА-ЛА-МА-ГА, 2012. - 416 с.

ЛСД 2007 - Літературознавчий словник-довідник. / За ред. Р. Гром'яка, Ю. Коваліва, В. Теремка. - К. : ВЦ «Академія», 2007. - 752 с.

Політичні теорії : Антична думка (Платон, Аристотель, Демокріт, Піфагор). - [Електронний ресурс]. - Режим доступу : http://the-law.at.ua/publ/ politologija/politichna_teorija/politichni_teoriji_nikkolo_makiavelli/13-1-0-97

Проскурин 1997 - Проскурин Б. Английский политический роман XIX века (проблемы генезиса и эволюции) : дис. ... д-ра. филол. наук. - Москва, 1997. $-374 \mathrm{c}$. 